\title{
Ball Milling as a Tool Towards Solubility Problems in Synthesis - Simple and Solvent-free Preparation of $\mathrm{K}\left[\mathrm{B}(\mathrm{CN})_{4}\right]$
}

\author{
Roland H. Pawelke
}

\begin{abstract}
A simple ball milling route to the tetrayanoborate anion is presented: The $\mathrm{K}\left[\mathrm{B}(\mathrm{CN})_{4}\right]$ synthesis is one fine example, how a synthesis problem based on solubility may be solved by a ball milling approach. The solid state ${ }^{13} \mathrm{C}$ - and ${ }^{11} \mathrm{~B}-\mathrm{MAS}-\mathrm{NMR}$ spectra have been recorded.
\end{abstract}

The tetracyanoborate anion $\left[\mathrm{B}(\mathrm{CN})_{4}\right]^{-}$has an electrochemical stability that is comparable to that of the tetrafluoroborate $\left[\mathrm{BF}_{4}\right]^{-}$or the hexafluorophosphate $\left[\mathrm{PF}_{6}\right]^{-}$anion. But unlike the latter, it is practically inert towards hydrolysis. That makes the tetracyanoborate anion a promising electrolyte component for advanced electrochemical systems: feasibility studies on solar cells ${ }^{1,2}$ and batteries ${ }^{3,4}$ have been already done. The $\left[\mathrm{B}(\mathrm{CN})_{4}\right]^{-}$anion has been observed for the first time in 1967 by BESSLER et al. in $\operatorname{Ag}\left[\mathrm{B}(\mathrm{CN})_{4}\right] ;^{5}$ the formation of this compound remained merely an analytical fact for the next 33 years. The scientific focus on new complex anions and ionic liquids around the turn of the millennium led to a renewed interest in the $\left[\mathrm{B}(\mathrm{CN})_{4}\right]^{-}$anion. The preparative synthesis of the $\left[\mathrm{B}(\mathrm{CN})_{4}\right]^{-}$anion was achieved by BERNHARDT et al:: $\mathrm{K}\left[\mathrm{B}(\mathrm{CN})_{4}\right]$ is an obvious starting materials for follow-up applications; but the chemical straightforward reaction of $\mathrm{BCl}_{3}$ and $\mathrm{KCN}$ is not a feasible route due to the lack of a suitable solvent for both reactants (Eq.1).

$4 \mathrm{KCN}+\mathrm{BCl}_{3} \longrightarrow \mathrm{H}\left[\mathrm{B}(\mathrm{CN})_{4}\right]+3 \mathrm{KCl}$

This solubility problem makes the wet-chemical preparation of $\mathrm{K}\left[\mathrm{B}(\mathrm{CN})_{4}\right]$ a three-step procedure: ${ }^{6}\left[\mathrm{NBu}_{4}\right]\left[\mathrm{B}(\mathrm{CN})_{4}\right]$ is prepared in the first step from $\left[\mathrm{NBu}_{4}\right] \mathrm{Br}, \mathrm{BCl}_{3}$ and $\mathrm{KCN}$, but the reaction lasts around one week in refluxing toluene or $O$ xylene ( $75 \%$ yield). The preparation of $\mathrm{K}\left[\mathrm{B}(\mathrm{CN})_{4}\right]$ from $\left[\mathrm{NBu}_{4}\right]\left[\mathrm{B}(\mathrm{CN})_{4}\right]$ requires two further cation exchange steps. This approach seems too complicated for the preparation of $\mathrm{K}\left[\mathrm{B}(\mathrm{CN})_{4}\right]$, especially on a larger scale. Subsequently, a thermal sinter process ${ }^{7}$ was developed (Eq.2) and the first applications of tetracyanoborate compounds were filed for patent. ${ }^{8-10}$ The ceramic synthesis starts from $\mathrm{K}\left[\mathrm{BF}_{4}\right]$ as boron source with a large exesses of $\mathrm{LiCl}$ and $\mathrm{KCN}$. The presence of $\mathrm{LiCl}$ lowers the melting point of the mixture and destabilizes
$\mathrm{K}\left[\mathrm{BF}_{4}\right]+9 \mathrm{LiCl}+9 \mathrm{KCN} \underset{\text { up to } 70 \%}{\stackrel{280-340{ }^{\circ} \mathrm{C}}{\longrightarrow}} \mathrm{K}\left[\mathrm{B}(\mathrm{CN})_{4}\right]+$ byproducts

the B-F bond; the reaction mixture is sintered at $280-340{ }^{\circ} \mathrm{C}$. The reaction yields a black solid, consisting of $\mathrm{K}\left[\mathrm{B}(\mathrm{CN})_{4}\right]$, $\mathrm{LiF}$, residual $\mathrm{KCN}$ and less identifiable products. Although the yield of this reaction is fairly good, the stoichiometric product-to-waste ratio of this reaction is not favourable, relatively precious fluoride is discarded as $\mathrm{LiF}$ and there are substantial amounts of residual KCN after the reaction. A non-thermic, solvent-free synthesis method could still work with the simple $\mathrm{BCl}_{3} / 4 \mathrm{KCN}$ reaction system. The activation energy for a chemical reaction is usually delivered by heat and/or electromagnetic irradiation. Alternatively, according to the first law of thermodynamics, this energy amount may also be provided by mechanic action/work. ${ }^{11-13}$ In practice, ball mills are approved tools for this: those commonly used are either of the vibratory or plantetary construction type. Mechanic activation by ball milling may be understood as an inverse Jahn-Teller effect, ${ }^{13}$ with the excess energy delivered by pressure and shear forces being stored by the formation of non-equilibrium, non-stoichiometric defects, structural distortions and additional intergrain boundaries. The smaller particle sizes and higher defect concentrations brought about by mechanic action lead to a higher reactivity and such activated materials may undergo polymorphic phase transitions or amorphization. ${ }^{14}$ In the case of multiple reactants, a chemical reaction between these may be activated. KAUPP has emphasized the difference between such a "mechanically activated" reaction and "mechanochemistry" in the narrow sense of the word. ${ }^{15}$ The number of examples from various fields of research $^{16-19}$ could suggest otherwise, but ball milling is far away from being an etablished method in synthetic chemistry. From the common wet-chemical point of view, it has still a somewhat exotic or even slightly alchemic flair. The difficulty in quantifying the energy input may be partly responsible for that and the mechanism(s) during a ball milling reaction are not very well understood at all; reaction conditions are often rather experiental. Assuming that solubility in the wetchemical sense should not be an issue in a ball milling reaction, there is no apparent reason why a $\mathrm{BCl}_{3} / 4 \mathrm{KCN}$ 
reaction setup should not work. The formation of $\mathrm{KCl}$ should add a strong thermodynamic momentum in favour of the exchange. Unfortunately, $\mathrm{BCl}_{3}$ is a very reactive and corrosive gas. Although such a gas-solid ball milling process is possible in a special milling vial, this would not be a step towards a simplified reaction setup. However, solid Lewis-adducts of $\mathrm{BCl}_{3}$ can be used like any other solid chemical in a ball mill. The commercially available dimethyl sulfide adduct of $\mathrm{BCl}_{3}$ is a promising material for a feasibility study and was used in a ball milling reaction according to Eq.(3). The reaction mixture was analyzed by ${ }^{11} \mathrm{~B}$ - and ${ }^{13} \mathrm{C}$-NMR-spectroscopy (see the supplementary data) and $\mathrm{K}\left[\mathrm{B}(\mathrm{CN})_{4}\right]$ was identified by the characteristic ${ }^{11} \mathrm{~B}-\mathrm{NMR}$ signal at $-38.4 \mathrm{ppm}$ (lit. ${ }^{6} \delta_{\mathrm{B}}=-38.6$ ppm). The characteristic ${ }^{13} \mathrm{C}$-signal of $\mathrm{K}\left[\mathrm{B}(\mathrm{CN})_{4}\right]$ can be seen at $123.4 \mathrm{ppm}$.

Energy input (800 rpm) and milling time (2 h) are relatively high and long for a ball milling metathesis, but these reaction conditions were deliberately chosen to ensure complete conversion of the KCN reactant. Indeed, no residual KCN was observed in the ${ }^{13} \mathrm{C}$-NMR spectrum (lit. ${ }^{20} \delta_{\mathrm{C}}=165.8 \mathrm{ppm}$ ) of the raw material after milling and therefore no workup with alkaline $\mathrm{H}_{2} \mathrm{O}_{2}$ was necessary. It should be mentioned, that ball milling under these conditions causes a considerable temperature rise in the vial and that heat from friction is an unfavourable factor in ball milling of sensitive materials (e.g. $\mathrm{AlH}_{3}{ }^{21}$ ). In such cases, the temperature may be controlled by an intervall milling procedure or by using a cryo-mill. $\mathrm{K}\left[\mathrm{B}(\mathrm{CN})_{4}\right]$ can be isolated by extraction using acetone. After evaporation of solvent, a brown crystalline mass is obtained in $65 \%$ yield. The $\mathrm{K}\left[\mathrm{B}(\mathrm{CN})_{4}\right]$ content of this crude product is estimated to $90 \%$ from ${ }^{11} \mathrm{~B}-\mathrm{NMR}$ integration, the ${ }^{13} \mathrm{C}-\mathrm{NMR}$ spectrum shows solely the signal of $\mathrm{K}\left[\mathrm{B}(\mathrm{CN})_{4}\right]$. Recrystallization from water yields pure $\mathrm{K}\left[\mathrm{B}(\mathrm{CN})_{4}\right]$ (workup procedure not optimized, Fig. 1). The solid state ${ }^{13} \mathrm{C}$ - and ${ }^{11} \mathrm{~B}$-MAS-NMR spectra of $\mathrm{K}\left[\mathrm{B}(\mathrm{CN})_{4}\right]$ were also recorded (Fig. 2): the ${ }^{11} \mathrm{~B}$ signal appears at $-37.4( \pm 0.2)$ ppm as a relatively sharp signal (FWHH $50 \mathrm{~Hz}$ ). The central line of the ${ }^{13} \mathrm{C}$-signal appears at $126.5( \pm 0.2) \mathrm{ppm}$. The exceptional stability of $\mathrm{K}\left[\mathrm{B}(\mathrm{CN})_{4}\right]$ and its relatively sharp ${ }^{11} \mathrm{~B}$-MAS-NMR signal may qualify this compound as a secondary standard for ${ }^{11} \mathrm{~B}-\mathrm{MAS}-\mathrm{NMR}$ spectroscopy. This feasibility study has shown that $\mathrm{K}\left[\mathrm{B}(\mathrm{CN})_{4}\right]$ can be easily prepared from the solid Lewis-adduct $\mathrm{BCl}_{3} \cdot \mathrm{SMe}_{2}$ and a stoichiometric amount of KCN by a ball milling reaction (yield $~ 50 \%$ ). There is much room for improvements and any application on larger scale would require an in-depth optimization of the reaction setup. But the isolated yield of this unoptimized reaction assay is already comparable to those of the established thermal sinter process. This ball milling route represents the chemically most straightforward synthesis of the $\left[\mathrm{B}(\mathrm{CN})_{4}\right]^{-}$anion and may be the method of choice for the preparation of $\mathrm{K}\left[\mathrm{B}(\mathrm{CN})_{4}\right]$ on a larger scale; therefore this principle has been filed for patent. ${ }^{22}$
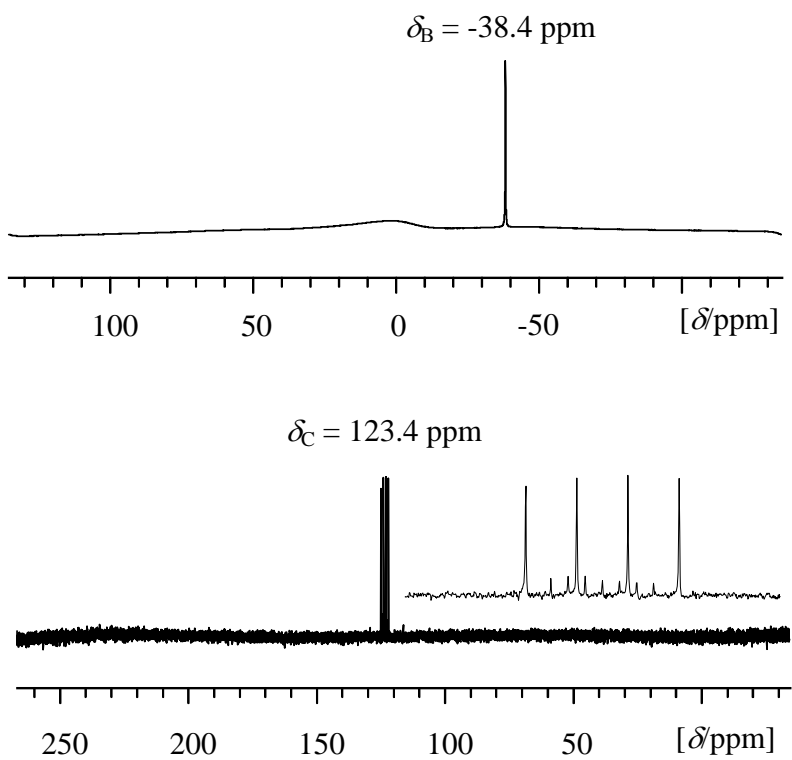

Fig. $1{ }^{11} \mathrm{~B}$ - and ${ }^{13} \mathrm{C}-\mathrm{NMR}$ spectra of $\mathrm{K}\left[\mathrm{B}(\mathrm{CN})_{4}\right]$ prepared according to Eq.(3) after recrystallization from water. The spectra are in excellent accordance with the literature. ${ }^{6}$

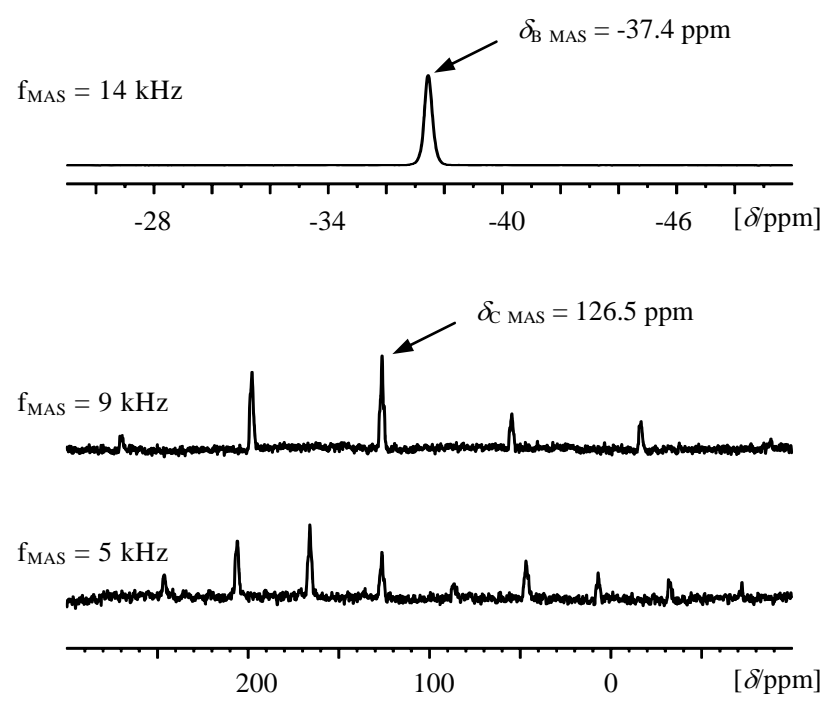

Fig. $2{ }^{11} \mathrm{~B}$ - and ${ }^{13} \mathrm{C}-\mathrm{MAS}-\mathrm{NMR}$ spectra of $\mathrm{K}\left[\mathrm{B}(\mathrm{CN})_{4}\right]$.

The benefits and the potential of ball milling as a preparative technique are yet to be fully recognized by the synthetic community. It has been a concern of this letter to emphasize the potential of ball milling and increase awareness of this method. 


\section{Acknowledgements}

I would like to thank the Max-Planck-Society for financial funding and Dr. B. Zibrowius for his assistance in recording and analyzing the solid state MAS-NMR spectra. Finally, I would like to thank Prof. Dr. F. Schüth for his permission to work freely on this "project-of-opportunity", although it was not directly related to my $\mathrm{PhD}$ thesis.

\section{Experimental section}

Chemicals were obtained from Sigma-Aldrich chemical company in purity of at least $98 \%$. Reactive milling was done in a Fritsch Pulverisette P7 ball mill: the milling vials were loaded in an argon-filled glove box $\left(\mathrm{O}_{2}<2\right.$ ppm, $\mathrm{H}_{2} \mathrm{O}<1$ $\mathrm{ppm}) .{ }^{11} \mathrm{~B}$ - and ${ }^{13} \mathrm{C}$-NMR spectroscopy in solution $\left(\mathrm{D}_{2} \mathrm{O}\right)$ was done on a Bruker DPX 300 spectrometer. The ${ }^{13} \mathrm{C}$ - and ${ }^{11} \mathrm{~B}$ MAS-NMR measurements were done on a Bruker Avance $500 \mathrm{WB}$ spectrometer at a resonance frequency of $125.8 \mathrm{MHz}$ $\left({ }^{13} \mathrm{C}\right)$ and $160.5 \mathrm{MHz}\left({ }^{11} \mathrm{~B}\right)$, using a double-bearing MAS probe (DVT BL4). To remove the carbon background signal of the probe, a pulse sequence consisting of a $90^{\circ}$ pulse $(3.6 \mu \mathrm{s})$ followed by two $180^{\circ}$ pulses with an appropriate phase cycling was applied. ${ }^{23}$ A repetition time of $240 \mathrm{~s}$ was used. The ${ }^{13} \mathrm{C}$-chemical shift was referenced to neat TMS, the ${ }^{11} \mathrm{~B}$-chemical shift to $\mathrm{BF}_{3} \cdot \mathrm{OEt}_{2}$, using a boron-containing zeolithe as secondary standard. ${ }^{13} \mathrm{C}$-MAS-NMR spectra were recorded at $\mathrm{f}_{\text {MAS }}=5$ and $9 \mathrm{kHz}$, the ${ }^{11} \mathrm{~B}$-MAS-NMR spectrum at $\mathrm{f}_{\mathrm{MAS}}=14 \mathrm{kHz} .1 .63 \mathrm{~g}(9 \mathrm{mmol}) \mathrm{BCl}_{3} \cdot \mathrm{SMe}_{2}$ and $2.39 \mathrm{~g} \mathrm{(36}$ mmol) KCN were placed in a $45 \mathrm{~mL}$ steel-vial with seven balls of the same material ( $\varnothing 15 \mathrm{~mm}$, ball-to-powder-ratio 24:1). The milling vial was sealed with insulation tape and the reaction mixture milled for $2 \mathrm{~h}$ at $800 \mathrm{rpm}$. After milling, the crude reaction mixture was three times stirred in approx. $50 \mathrm{~mL}$ of acetone and filtered. The filtrates were combined and the solvent evaporated. A crystalline brown mass (900 mg, $65 \%$ ) is obtained, ${ }^{11} \mathrm{~B}$ - and ${ }^{13} \mathrm{C}-\mathrm{NMR}$ spectra of this material verify $\mathrm{K}\left[\mathrm{B}(\mathrm{CN})_{4}\right]$ in $\sim 90 \%$ purity which may be further purified by recrystallization from water.

\section{References}

1. Y. Bai, Y. Cao, J. Zhang, M. Wang, R. Li, P. Wang, S. M. Zakeeruddin and M. Gratzel, Nat. Mater. , 2008, 7, 626-630.

2. D. Kuang, C. Klein, Z. Zhang, S. Ito, J.-E. Moser, S. M. Zakeeruddin and M. Gratzel, Small, 2007, 3, 2094-2102.

3. EP Pat., 1819005, 2007.

4. J. Scheers, P. Johansson and P. Jacobsson, J. Electrochem. Soc., 2008, 155, A628-A634.

5. E. Bessler and J. Goubeau, Z. Anorg. Allg. Chem., 1967, 352, 67-76.

6. E. Bernhardt, G. Henkel and H. Willner, Z. Anorg. Allg. Chem., 2000, 626, 560-568.

7. E. Bernhardt, M. Finze and H. Willner, Z. Anorg. Allg. Chem., 2003, 629, 1229-1234.

8. DE Pat., 102004007610, 2005.

9. WO Pat., 2005021661, 2005.

10. DE Pat., 10306617, 2004.

11. V. V. Boldyrev and K. Tkacova, J. Mater. Synth. Process., 2000, 8, 121-132.
12. J. F. Fernandez-Bertran, Pure Appl. Chem. , 1999, 71, 581-586.

13. J. J. Gilman, Science, 1996, 274, 65.

14. N. Z. Lyakhov, T. F. Grigoryeva and A. P. Barinova, J. Therm. Anal. Calorim., 2005, 82, 741-746.

15. G. Kaupp, CrystEngComm, 2009, 11, 388-403.

16. C. Suryanarayana, Rev. Adv. Mater. Sci., 2008, 18, 203-211.

17. A. Bruckmann, A. Krebs and C. Bolm, Green Chem., 2008, 10, 1131-1141.

18. A. Pichon and S. James, Chem. World, 2007, 4, 35.

19. A. L. Garay, A. Pichon and S. L. James, Chem. Soc. Rev., 2007, 36, 846-855.

20. C. Kappenstein, J. Bouquant and R. P. Hugel, Inorg. Chem., 1979, 18, 2615-2617.

21. T. Sato, K. Ikeda, H. W. Li, H. Yukawa, M. Morinaga and S. Orimo, Mater. Trans., 2009, 50, 182-186.

22. WO Pat., 2010032102, 2010.

23. D. G. Cory and W. M. Ritchey, J. Magn. Reson., 1988, 80, 128-132. 
